Covered in: ERIH PLUS, HeinOnline, CEEOL, Index Copernicus, CrossRef, CrossCheck, J-GATE, Google Scholar, Ideas RePeC, Econpapers, Socionet, KVK, WorldCat.

2019, Volume 7, Issue 1, pages: 12-25 | doi: 10.18662/lumenlaw/14

\section{Cases when UN was Surperflous between 2003-2010}

\section{Gabriel-Vasile PLAMADĂ ${ }^{1}$}

${ }^{1}$ Stefan cel Mare University of Suceava, Romania, plamadag@gmail.com
Abstract: Throughout history, the UN's role in decolonising Namibia, in monitoring human rights in San Salvador, in the Nicaraguan elections, in the administration of Cambodia, and in most peacekeeping missions can not be denied.

"The World peace" has never been able to be made, and even 65 years after the constitutive act was signed, instability and insecurity continue to exist. The recent events, as will be shown below, will show that there are still wars of aggression, that contemporary events abound in examples of peace and war crimes, against which action is based on political criteria and not legal.

Keywords: peace; UN; law; conflict; war; official; politics; declaration.

How to cite: Plamadă, G.-V. (2019). Cases when UN was Surperflous between 2003-2010. Logos Universality Mentality Education Novelty: Law, 7(1), 12-25. doi:10.18662/lumenlaw/14 



\section{Introducere}

In decursul istoriei nu poate fi contestat rolul pe care ONU l-a avut în decolonizarea Namibiei, în monitorizarea drepturilor omului în San Salvador, în alegerile din Nicaragua, în administrarea Cambodgiei, precum şi în cele mai multe misiuni privind supravegherea forțelor de menținere a păcii. Nu pot face subiectul discuției oferirea de ajutor umanitar victimelor conflictelor, rolul avut în atenuarea foametei cronice şi a sărăciei rurale în țările în curs de dezvoltare sau prevenirea pescuitului excesiv, toate aceste realizări apărând pe site-ul Națiunilor Unite ca făcând parte dintr-o listă cu 70 de moduri în care organizația a schimbat lumea ("70 Ways the UN Makes A Difference", n.d.).

Insă din această enumerare pot face cu siguranță obiectul controverselor, menținerea păcii şi securității, întărirea dreptului internaţional şi prevenirea proliferării nucleare.

Forțele de menținere a păcii au fost de folos în Haiti şi Cambodgia, dar nu au reuşit să oprească războiul civil din Angola sau să împiedice genocidele din Somalia, Bosnia Herzegovina sau Rwanda. Pe fondul intereselor divergente ale membrilor permanenți şi al birocrației, numărul victimelor din Somalia se află în jurul valorii de 15-20.000, în Rwanda la o cifră ce variază în funcție de oficial-neoficial de la 800.000 la 2 milioane şi jumătate de oameni, iar în Bosnia-Herțegovina ca simple exemple, cifra se prefigurează în jurul valorii de 200.000 ("Statement by H. E. Dr. Haris Silz̧jdzic, Chairman of the Presidency of Bosnia and Herzegovina", 2008, September 23rd).

$\mathrm{Nu}$ ar fi posibilă o analiză exhaustivă a tuturor conflictelor în care ONU s-a implicat şi a rezultatelor acesteia. Cert este că din aproximativ 200 de conflicte ce au avut loc de la înființarea organizației şi până în prezent, singura situație când s-a acționat în deplin acord al membrilor permanenți, fără absentarea unuia dintre ei şi înainte de întreprinderea unei intervenții individuale, adică aşa cum ar fi trebuit să fie sistemul decizional, a fost ca urmare a invaziei Kuweitului de către Irak.

„Pacea mondială” nu a reuşit în niciun caz să fie obținută şi chiar la 65 de ani de la semnarea actului constitutiv, starea de instabilitate şi de insecuritate continuă să existe. Evenimentele recente, aşa cum vor fi prezentate în cele ce urmează, vor arăta faptul că încă există războaie de agresiune, că evenimentele contemporane abundă în exemple de crime împotriva păcii şi crime de război, împotriva cărora se iau acțiuni care au la bază criterii politice şi nu juridice. 


\section{Irak}

La 20 martie 2003, Statele Unite, Marea Britanie şi Spania declanşează împotriva Irakului o acțiune militară menită să pună capăt proliferării de către acesta a armelor de distrugere în masă şi a legăturii regimului lui Saddam Hussein cu organizația teroristă Al-Qaida.

Înainte ca „Operation Iraqi Freedom” să fie declanşată, secretarul de stat american la acea dată, Colin Powell, a fost implicat în negocieri diplomatice în Consiliul de Securitate, expunând ideea că „o acțiune rapidă şi eficientă se impunea asupra Irakului”, pentru ca „pacea şi securitatea internaţională să fie menţinute" ("Statement by H. E. Dr. Haris Silrzjdzic, Chairman of the Presidency of Bosnia and Herzegovina", 2001, September 12th).

Pe 29 mai 2003, președintele George W. Bush declara, într-un interviu acordat unei televiziuni poloneze că ,am găsit arme de distrugere în masă. Am găsit laboratoare biologice". Cu câteva zile înainte, președintele american primise raportul echipei de experți care analizase cele două laboratoare descoperite în Irak, care arăta faptul că laboratoarele erau destinate producerii de hidrogen pentru baloane meteorologice ("Study: Bush, aides made 935 false statements in run-up to war", 2008).

In 5 februarie 2003, într-o adresă către Consiliul de securitate al SUA, Collin Powell scria: „Ceea ce vă oferim noi sunt fapte și concluzii bazate pe dovezi solide, furnizate de serviciile secrete".

Toate acestea au fost declarate în contextul în care, specialişti dintre cei mai respectați ai Naţiunilor Unite, precum Hans Blix, fost director general al Agenției Internaționale pentru Energie Atomică, cel care a condus inspecțiile efectuate în Irak, şi-au prezentat concluziile în două rapoarte pe care le-au pus la dispoziția inclusiv a Consiliului de Securitate, concluzionând hotărâtă că „era foarte improbabil să existe asemenea arme” în Irak. Deranjat la un moment dat de declarațiile Statelor Unite referitoare la deținerea de către Irak a armelor şi necesitatea intervenţiei, Colin Powell li s-a adresat direct oficialilor de la Washington, întrebând „Sunt rapoartele (Naţiunilor Unite) cu totul necitate la sud de Hudson?” (de către oficialii de la Washington) ("Saddam Hussein nu avea arme de distrugere in masă", 2004, October 7th).

În ampla cercetare ştiințifică efectuată de Joseph E Stiglitz şi Linda J. Bilmes este confirmată concluzia potrivit căreia Irakul nu deținea arme de distrugere în masă. Totodată, cei doi cercetători au mai susținut o idee care sa dovedit adevărată, şi anume aceea că, nu numai că nu exista o legătură între Al-Qaida şi Irak, dar mai mult, ,invazia risca să creeze şi mai mulți terorişti” ("'Saddam Hussein nu avea arme de distrugere în masă"', 2004, October 7th). 
Statele Unite au încercat cu încăpăţânare să încadreze acțiunea îndreptată împotriva Irakului ca fiind autoapărare în ciuda faptului că, aşa cum am demonstrat, nu exista nicio dovadă concretă în acest sens. Nici în cazul în care s-ar fi dovedit reală dezvoltarea armelor de distrugere în masă, intervenția nu ar fi fost justificată din punct de vedere juridic. Şi asta pentru că, după invazia Kuweitului din 1990, Consiliul de Securitate a autorizat un răspuns împotriva Irakului, iar la terminarea ostilităților, i-au fost interzise dezvoltarea programelor de producerea a armelor nucleare şi au fost luate o serie de sancțiuni cu privire la acesta.

Aşadar, în pofida rapoartelor Națiunilor Unite care s-au dovedit a fi adevărate, Statele Unite, Marea Britanie şi Spania au întreprins o acțiune militară fără a se afla în nici una din situațiile legitime din punct de vedere al uzului de forță, au utilizat în rapoartele difuzate informații false sub pretextul protecției informațiilor clasificate şi au condus o amplă propagandă în favoarea invaziei.

Neavând acordul Consiliului de Securitate pentru această intervenție şi în conformitate cu dreptul internaţional, invazia Irakului din 20 mai 2003 constituia o crimă contra păcii care trebuia să angajeze răspunderea penală a celor ce se făceau vinovați de aceasta.

$\mathrm{O}$ astfel de reacție a ONU era practic imposibilă din cauza modului în care Organizația a fost proiectată, având în vedere că doi dintre agresori erau membri permanenți ai Consiliului de Securitate şi beneficiau de dreptul de veto. Prin urmare a mai rămas o singură variantă de urmat în acest sens, şi anume adoptarea unei rezoluții la 22 mai 2003, prin care să se legitimeze această acțiune, în temeiul cap al VII-lea din Cartă (Rezoluţia nr. 1493/2003 adoptată de Consiliul de Securitate in cadrul celei de-a 4.797-a intruniri, la 28 iulie 2003).

Deşi acțiunea a primit prin Rezoluţia nr. 1483 legitimitate, în desfăşurarea operațiilor trebuiau avute în vedere normele de drept internațional umanitar, pe care însăşi rezoluția le prevede, subliniind faptul potrivit căruia, (Consiliul de Securitate) „Invită toate părțile implicate să respecte pe deplin obligațiile ce le revin în temeiul dreptului internaţional, inclusiv, în special Convențiile de la Geneva din 1949 şi regulamentele de la Haga din 1907'".

$\mathrm{Cu}$ toate acestea, sondajele privind numărul irakienilor morți în timpul intervențiilor din Irak se prezintă însă în felul următor: o cercetare realizată de organizația britanică Opinion Research Bussines, arată că aproximativ 1,2 milioane de irakieni au murit în condiţii violente. Metoda prin care s-a ajuns la aceste cifre a fost prin intervievarea a mii de cetățeni irakieni, care au declarat numărul de decese înregistrate în rândurile familiilor 
şi cunoscuților. Revista medicală Lancet declarase în 2006 că 80\% din decesele din Irak în perioada menționată au fost determinate de intervențiile militare şi nu din cauze naturale. Acest studiu estimează numărul de morţi pe săptămână la aproximativ 5000. La acestea se adaugă aproape cinci milioane de irakieni refugiați, conform Agenției Națiunilor Unite pentru Refugiați şi Migrație ("Iraq conflict has killed a million Iraqis: survey", 2018; "ORB survey of Iraq W ar casualties", n.d.).

Statele Unite nu au ratificat Statutul de la Roma, prin urmare Tribunalul Penal Internațional nu se poate implica în tragerea la răspundere a celor vinovați, chiar dacă aceştia nu au fost judecați nici în tribunalele interne.

\section{Georgia}

Națiunile Unite s-au implicat în stabilizarea conflictelor din Georgia începând cu Rezoluția nr. 858 din 1993, prin care Consiliul de Securitate a iniţiat Misiunea de Observatori ai ONU în Georgia (United Nations Observer Mission in Georgia - UNOMIG) pentru a se asigura de respectarea acordului de încetarea a focului încheiat de guvernul Georgiei şi autorităţile Abhaziei în 27 iulie 1993. Mandatul original nu a fost validat şi prin Rezoluția nr. 881 a Consiliului, misiunea a primit un mandat interimar, în scopul monitorizării şi respectiv raportării situației. Prin rezoluția nr.937(1994) a fost autorizată creşterea autorității UNOMIG şi extinderea mandatului în principal pentru verificarea implementării acordului de încetare a focului și observarea misiunilor de menținere a păcii ale CSI.

În 1996, prin Rezoluția nr.1077 este înființat Biroul Naţiunilor Unite pentru protecția şi promovarea drepturilor omului în Abhazia şi Georgia.

Rezoluția nr.1494 din 2003 a Consiliului întărește recomandarea Secretarului General ca „O componentă de poliție a Națiunilor Unite, formată din 20 de ofițeri să fie adăugată misiunii UNOMIG, în primul rând pentru a-i întări capacitatea de a îndeplini mandatul său şi în particular pentru a contribui la crearea condițiilor favorabile pentru reîntoarcerea în siguranță şi cu demnitate a refugiaților”.

În anii următori, aproape ciclic, Consiliul de Securitate a continuat să emită, de regulă două rezoluții aproape identice anual în privința situației din Georgia.

Pe 15 aprilie 2008, este adoptată Rezoluția nr.1808 în care este reiterată importanța menținerii forțelor separate şi a păstrării acordului de încetare a focului, sunt salutate îmbunătățirile în privința situației per ansamblu a securității, le este adresată ambelor părți cererea de a consolida şi 
a extinde aceste îmbunătățiri, accentuează importanţa unei cooperări apropiate şi eficiente între UNOMIG şi forțele de menținere a păcii ale CSI, cele care joacă un rol important în stabilizarea zonei şi, nu în ultimul rând, sunt reafirmate angajamentele statelor membre în privința suveranității, independenței, şi integritătii teritoriale a Georgiei şi suportul tuturor eforturilor Naţiunilor Unite care sunt ghidate de determinarea lor în promovarea acordului între Georgia şi Abhazia, numai prin mijloace paşnice şi în cadrul rezoluțiilor Consiliului de Securitate.

La data de 8 august 2008, armata rusă declanşa primele raiduri aeriene pe teritoriul Georgiei, ca răspuns al pătrunderii trupelor georgiene pe teritoriul Osetiei de Sud. După dislocarea soldaților ruşi pe teritoriul georgian, Preşedintele Georgiei, Mihail Saakaşvili, declara că cele două state se aflau în stare de război, iar preşedintele rus, Dimitri Medvedev, acuza Georgia de provocarea unui dezastru umanitar în Osetia de Sud: „Forțele ruse de menținere a păcii trebuie să ajute populaţia civilă, după agresiunea părții georgiene. Cei care au provocat această criză umanitară trebuie traşi la răspundere pentru ceea ce au făcut" (www.reuters.com).

La o primă vedere, în condițiile în care Organizația Naţiunilor Unite stabileşte drept principiu „rezolvarea pe cale paşnică a diferendelor” şi ca unice justificări ale folosirii forței dreptul la autoapărare şi acţiunile în temeiul cap al VII-lea al Cartei ONU, este greu de argumentat în vreun fel din punct de vedere juridic, modalitatea prin care două state membre pot ajunge într-o „stare de război”.

Şi de această dată, după cum poate fi observat, un membru permanent al ONU îşi arogă calitatea de gardian al păcii mondiale şi acționează din proprie inițiativă în sensul ajutării populației civile, chiar mai mult prin „forțe ruse de menținere a păcii”.

Acest ajutor benevol acordat populatiei civile din Osetia, a condus în rândurile populației civile din Georgia la 228 victime, 973 de răniți şi la distrugerea locuințelor, a unor puncte de interes economic şi infrastructural ("FACTBOX: Facts about the 2008 war in Georgia", 2009).

După cum era de aşteptat în cazul implicării unui membru permanent într-o astfel de situație, reacţiile împotriva acestor evenimente au fost timide, iar ale Organizației Naţiunilor Unite doar simbolice (Consiliul de Securitate al ONU nereuşind să ajungă la un acord pentru votarea unei rezoluții referitoare la evenimentele din Georgia, din cauza folosirii dreptului de veto de către Rusia).

Fără a mă mai angaja într-o dezbatere legată de motivele strategice ce au primat şi de această dată în faţa forței dreptului şi spiritului justiţiar, voi prezenta câteva aspecte menite să sublinieze funcționalitatea actuală a ONU. 
Fostul premier al Marii Britanii, Gordon Brown, considera într-un articol apărut pe 31 august 2008 în publicația „The Guardian” că ,agresiunea Rusiei este periculoasă şi inacceptabilă” (Brown, 2008; Harding \& Borger, 2008; Nichol, 2009).

Intr-un articol publicat de Washington Post, pe 18 august, preşedintele francez, Nicholas Sarkozy, vorbea de „răspunsul brutal şi disproporţionat" al armatei ruse. Preşedinţii Estoniei, Letoniei, Lituaniei şi Poloniei semnau împreună la 9 august o declarație prin care enunțau că, „date fiind acțiunile militare unilaterale ale forțelor militare ale Rusiei, vom folosi toate mijloacele pe care le avem la dispoziție, ca şefi de state, pentru a ne asigura că agresiunea împotriva unui mic stat din Europa nu va trece neobservată sau semnalată doar prin declarații inutile şi care pun egalitate între victime şi agresori”, cerând totodată ca „UE şi NATO să joace un rol cheie în securizarea libertății, securității şi prosperităţii pentru statele din zona europeană de vecinătate” (dar ONU?, n.a). Preşedinții Estoniei, Lituaniei, Poloniei şi premierul Letoniei insistă printr-o declarație oficială din 12 august pentru, ,incetarea imediată a focului, sfârşitul agresiunii şi a continuării ocupării Georgiei suverane...” (Maier, 2008).

După cum se poate observa, statele membre ale Organizației Naţiunilor Unite nu s-au ferit să catalogheze în mod individual acest act ca fiind unul de „agresiune”, „brutal”, „disproporționat”, „periculos” şi „,inacceptabil” care „nu va trece neobservat sau semnalat doar prin declaratii inutile şi care pun egalitate între victime şi agresori”.

Reacția concretă în urma acestei acțiuni nu a fost decât aceea a Uniunii Europene de a crea Misiunea Civilă de Monitorizare a UE în Georgia (European Union Mission of Monitorization - EUMM) pentru a contribui la stabilizarea situaţiei în Georgia şi în regiune, aceasta având în vedere "monitorizarea aspectelor civile ale activităţii părților în conflict, inclusiv din punctul de vedere al aplicării în totalitate a Acordului în şase puncte”. Misiunea a fost dislocată pentru o perioadă de un an, până la 14 septembrie 2009, dar la 27 iulie 2009, în cadrul reuniunii Consiliul de Afaceri Generale şi Relaţii Externe al UE (Conseil des Affaires Générales et Relations Exteriéures - CAGRE), s-a decis prelungirea mandatului misiunii cu un an, până la 14 septembrie 2010 (www.mae.ro).

Nicolas Dakuort, director al Departamentului Europa şi Asia Centrală din cadrul organizației non-guvernamentale Amnesty International a afirmat că: ,sute de mii de oameni vor trebui să accepte noua realitate apărută în urma conflictului, iar autorităţile poartă răspunderea pentru ca acest proces să se desfăşoare cât mai bine şi curând posibil. Până în prezent, nici unul dintre oficialii georgieni şi ruşi nu au fost traşi la răspundere pentru 
gravele încălcări ale legislației internaționale şi naţionale din momentul încheierii conflictului’".

\section{Fâşia Gaza}

Pe 27 decembrie 2008, Israelul lansa o ofensivă aeriană („Operation cast lead") împotriva mişcării islamiste Hamas din Fâşia Gaza, al cărei obiectiv declarat era să pună capăt tirurilor cu rachetă asupra teritoriului israelian.

Israelul se angaja, aşa cum a declarat, într-un „război fără milă” împotriva Hamas, începând cu 29 decembrie pentru a-l destabiliza, şi decreta sectorul frontalier al teritoriului palestinian ,zonă militară închisă”.

Pe 4 ianuarie 2009, a avut loc o reuniune a Consiliului de Securitate al ONU pentru a discuta situația din Gaza, însă la sfârşitul întâlnirii reprezentații statelor membre nu au reuşit să adopte o declaraţie comună.

Abia la data de 9 ianuarie, Consiliul de Securitate al ONU a aprobat, cu 14 voturi pentru şi o abţinere - cea a SUA, Rezoluţia nr. 1860 prin care le era cerut Israelului şi organizației Hamas să înceteze ostilităţile din Gaza, însă, ca şi cum aceasta ar fi avut un caracter facultativ, a fost respinsă de ambele părți aflate în conflict. O zi mai târziu, oficiali ai SUA au declarat că Washingtonul dorește o încetare imediată a focului, deși în cadrul votului din Consiliul de Securitate aceştia s-au abţinut. $\mathrm{Cu}$ toate acestea, armata israeliană a continuat să execute atacuri asupra a mai mult de 40 de obiective din Gaza.

Cu prilejul unei conferințe de presă organizată la Tel-Aviv, secretarul general al ONU, Ban Ki-Moon, a apreciat bilanţul victimelor din Gaza ca fiind inacceptabil. Totodată, oficialul a afirmat că un milion de cetățeni israelieni trăiesc zi de zi sub amenințarea loviturilor cu rachete, iar această stare trebuie să înceteze definitiv (Hotnews.ro, 2008).

Adunarea generală a ONU a votat pe 17 ianuarie o nouă rezoluție, conținând termenii celei adoptate la 9 ianuarie de către Consiliul de Securitate, prin care făcea un apel la încetarea imediată a focului. Nici acesteia nu i-a fost acordată mai multă atenție. Ostilitățile au continuat.

Bilanţul prezentat de BBC indica 13 militari israelieni ucişi în conflict. De partea palestinienilor, numărul morților a urcat la 1434.

In timpul conflictului, un obuz al artileriei israeliene a lovit sediul ONU din Gaza rănind trei persoane, mai multe proiectile de artilerie au lovit spitalul Al-Qods din Gaza, a fost bombardată o şcoală aflată sub coordonarea ONU, în urma incidentului rezultând uciderea a 4 cetățeni palestinieni şi rănirea altora, iar Agenția ONU de Ajutorare a Palestinienilor 
(United Nations Relief and Works Agency for Palestine Refugees in the Near East - UNRWA) a hotărât suspendarea acțiunilor sale din Fâşia Gaza, datorită riscurilor prea mari la care erau expuşi membri săi în fața atacurilor israeliene.

Şeful Agenției Umanitare a Națiunilor Unite, Sir John Holmes, s-a declarat „şocat de natura sistematică a distrugerilor" realizate în urma intervenției militare a Israelului în Faşia Gaza. Acesta a adăugat faptul că, din punct de vedere economic, Fâşia Gaza a fost aruncată cu câțiva ani sau chiar cu o decadă înapoi în timp, din cauza distrugerilor infrastructurii din regiune. Sir John Holmes a dat exemplul unei zone industriale din Gaza, unde toate clădirile industriale de pe o rază de un kilometru pătrat au fost distruse complet de bombele şi buldozerele israeliene.

Richard Falk, raportor ONU pentru drepturile omului în teritoriile palestiniene, declara într-un raport de 26 de pagini înmânat Consiliului ONU pentru Drepturile Omului că, în conformitate cu Convențiile de la Geneva, forțelor armate li se cere să facă distincție între ținte militare şi civili, şi afirma faptul că, „lansarea atacurilor este ilegală şi constituie crimă de război de o gravitate mare, conform legislației internaționale. Pe baza dovezilor preliminare disponibile, există motive să ajungem la această concluzie". Richard Falk a oferit acelaşi bilanţ al victimelor războiului ca şi centrul palestinian pentru drepturile omului - 1434 palestinieni ucişi, dintre care 960 civili. El a calificat atacurile israeliene ca fiind „un asalt masiv asupra unei aşezări urbane dens populate”, în care populația civilă a fost subiectul „unei forme inumane de conflict ce ucide, mutilează şi afectează mental" (Hotnews.ro, 2008). În altă ordine de idei, având în vedere că granițele erau închise, civilii nu aveau scăpare. În acest sens el a completat că interzicerea dreptului de a părăsi zona de război pentru refugiați constituie, de asemenea, crimă împotrivă umanităţii. Oficialul a sugerat ca actualul Consiliu de Securitate să stabilească un tribunal care să judece crimele de război din Gaza.

Raportul, prezentat de către Richard Goldstone, preşedintele Consiliului pentru Drepturile Omului din cadrul ONU, care se ocupă de anchetarea abuzurilor comise în timpul ofensivei israeliene asupra Fâşiei Gaza, critica tirurile de rachete cu fosfor alb asupra sediilor UNRWA, „atacul intenționat asupra spitalului al-Qods cu ajutorul obuzelor explozibile şi a celor cu fosfor" şi „atacul impotriva spitalului Al-Wafa” şi le cataloga drept „încălcări ale dreptului umanitar internațional” ("United Nations Fact Finding Mission on the Gara Conflict", n.d.; Human Rights Council, 2009).

Inaltul Comisar al ONU pentru Drepturile Omului, Navi Pillay, a declarat că „eşecul armatei israeliene în a ajuta civilii nevinovați constituie 
crimă de război”. Comisarul ONU a criticat de asemenea atacurile israeliene împotriva unor obiective „marcate clar cu semnele ONU şi unde se adăposteau civili, cu atât mai mult cu cât zeci de oameni, mai ales copii au fost răniţi în aceste atacuri deliberate". În egala măsură, Pillay susţinea şi că „un prim pas după încetarea ostilităţilor ar fi ca să aibă loc investigații credibile, imparţiale şi transparente pentru a se identifica toate violările Dreptului International Umanitar şi pentru stabilirea celor responsabili’”.

Intervenția Organizație Naţiunilor Unite s-a oprit şi de această dată la nivel declarativ.

\section{Kîrgîzstan}

Conflictele interetnice nu prezintă o noutate în Kîrgîzstan, însă în zilele de 11-13 iunie 2010, în mod special, violențe fără precedent au avut loc între kârgâzii majoritari şi minoritatea uzbecă, cuprinzând oraşele din sudul țării Oş, al doilea ca mărime, şi Djalal-Abad, locul natal al ex-preşedintelui Kurmanbek Bakiev. Bande bine înarmate au tras asupra etnicilor uzbeci, leau jefuit depozitele şi le-au incendiat casele, restaurantele, magazinele, sediile oficiale, teatrele. Cei care au scăpat cu viaţă au fugit spre granița cu Uzbekistan. Numai într-o singură zi, la 13 iunie, în aceste două oraşe au fost îngropați 100 de oameni, în timp ce alte cadavre zăceau pe străzi fără ca nimeni să le ridice. Datele oficiale arătau că 170 de persoane au fost ucise, dar Crucea Roşie susținea că numărul lor este de câteva sute. La 16 iunie datele oficiale indicau 187 de morți în conflict, 1966 de răniți, 300.000 de refugiați şi 765.000 de oameni afectați de evenimente. Conducătorul Centrului Regional al ONU pentru Diplomație Preventivă pentru Asia Centrală, declara la data de 18 iunie că o prezență de securitate internaţională ar putea fi necesară să calmeze situația tensionată şi să prevină o nouă erupție a violențelor. Acesta se declara şocat de extinderea violențelor, de numărul de morți şi de răniţi, de violența sexuală, de distrugerile şi jafurile care au avut loc (UN News, 2010).

Deşi luat prin surprindere de aceste acțiuni violente, guvernul de la Bişkek a trimis în zonă trupe militare pentru a întări forțele locale, care aveau dreptul de a folosi muniție de război, dar aşa cum președintele interimar, Roza Otunbaeva a recunoscut, autorităţile centrale pierduseră controlul şi aveau nevoie de ajutor extern.

Într-o rezoluție adoptată prin consens de către Consiliu de Securitate, acesta şi-a manifestat îngrijorarea pentru violențele declanşate, a făcut apel la încetarea acestora şi a solicitat întreprinderea unor investigații 
complete şi transparente în privinţa vinovaţilor de crimele comise (UN News, 2010).

In zonă nu au fost trimise forțe de menținere a păcii, Organizația Națiunilor Unite canalizându-şi efortul spre strângerile de fonduri necesare asistenței sutelor de mii de oameni afectați de conflictul interetnic din Kîrgîzstan.

Ar fi multe exemple ce arată capacititatea functionala a acestei organizatii cel mai graitor exemplu fiind cel al conflictului din Siria (Atrocităţile comise în Siria reprezintă „un eşec colectiv” al comunităţii internaționale, - secretarul general al ONU, Ban Ki-moon).

\section{Concluzii privind funcționalitatea ONU în gestionarea conflictelor recente}

În pofida tuturor definițiilor date crimelor internaționale de către Convențiile de la Geneva, Protocoalele Adiționale sau Tribunalele Penale Internaționale, ONU nu a reuşit să definească actul de agresiune. Această lacună legislativă, existentă încă din timpul Societăţii Naţiunilor, ce-i lasă politicului în mare parte competența încadrării unei acțiuni în sfera celor de agresiune, nu a făcut decât să cultive arbitrariul în aplicarea dreptului şi a răspunderii penale internaționale. Arbitrariul a condus la rândul său la scăderea credibilităţii organizației, fapt ce a generat aplicarea de măsuri individuale sau de către organizații de securitate care ar fi trebuit implicate doar prin hotărâri explicite ale Consiliului de Securitate, prin urmare ONU găsindu-se angrenat fără ieşire într-un cerc vicios.

Curtea Internațională de Justiție ar putea reprezenta un veritabil mijloc în vederea soluționării paşnice a diferendelor, în cazul în care s-ar sesiza din oficiu o dată cu apariția unui diferend şi dacă hotărârile sale ar avea pe lângă caracterul obligatoriu şi unul executoriu.

Curtea Penală Internațională este de asemenea o inițiativă lăudabilă în vederea pedepsirii încălcărilor grave ale dreptului internaţional dar aşa cum am prezentat într-un capitol anterior, nu poate fi sesizată decât în privința unui stat semnatar al Statutului şi după cum am văzut, cele care încalcă frecvent şi flagrant ordinea de drept nu fac parte din lista celor ce i-au acceptat jurisdicția. În altă ordine de idei, Consiliul de Securitate este cel căruia îi revine din nou rolul principal în declararea unui act ca fiind unul de agresiune şi prin această prevedere se ajunge din nou la punctul din care s-a pornit- blocajul decizional.

Paradoxul este că ineficiența a fost sesizată şi din interiorul organizației şi nu doar din exterior. În august 2000 spre exemplu, secretarul 
general de la acea dată, înainta o scrisoare Adunării Generale şi Consiliului de Securitate în care, într-un mod critic şi de un pragmatism fără precedent, a subliniat principalele disfuncții constate. Semnala atunci că „Potrivit Cartei ONU, organizația a fost înființată cu scopul de a salva generațiile viitoare de flagelul războiului. Îndeplinirea acestui obiectiv reprezintă cea mai importantă funcție a ONU. În ultima decadă, organizația a eşuat în mai multe rânduri să îşi atingă obiectivul fundamental, dar asta nu înseamnă că acest lucru se va repeta şi în viitor. Fără o schimbare semnificativă însă, a instituțiilor sale şi fără o reînnoire a asumării angajamentelor statelor membre, ONU nu va fi capabilă să execute misiunile critice de construcția şi menținerea păcii.”

In acest sens, Secretarul General al ONU a cerut DPKO să evalueze neajunsurile sistemului actual şi să facă recomandări realiste pentru efectuarea schimbărilor necesare înlăturării acestor deficiențe. Oficialul sublinia faptul că, pentru iniţiative preventive de reducere a tensiunilor şi de înlăturare a conflictelor, secretarul general al ONU are nevoie de un sprijin politic clar, puternic şi susţinut din partea statelor membre. In ceea ce priveşte succesul operaţiilor de menținerea păcii, s-a constatat că o infinitate de bune intenții nu pot înlocui capacitatea fundamentală de dislocare a unei forțe credibile în teren.

$\mathrm{Ca}$ un corolar al ideilor menţionate în paragrafele anterioare, condițiile esențiale pentru obținerea succesului în viziunea sa erau: sprijinul politic, dislocarea rapidă a unei forțe robuste în teren şi o strategie adecvată şi vizibilă de construcţie a păcii (United Nations, General Assembly, 2000).

La 18 ani de la redactarea acestui raport de către cel mai înalt funcționar public al ONU, nu au fost efectuate schimbări esențiale în concepția şi funcționarea organizației, iar rezultatul a putut fi constatat prin prezentarea sumară a modului în care aceasta a reacționat ca răspuns la cele mai recente conflicte armate.

Precursoarea ONU, Societatea Națiunilor, nu s-a dovedit a fi una funcțională, argumentul cel mai important în acest sens fiind izbucnirea celui de-al Doilea Război Mondial. Statele au încercat perfecționarea vechiului organism, înaintea semnării actului constitutiv la San Francisco, dar fără a rezolva cu adevărat problemele pe care Liga Naţiunilor le înfruntase.

Urmând acest fir şi evenimentele periculoase din istoricul ONU, s-ar putea desprinde concluzia că statele aşteaptă izbucnirea unui al treilea război mondial pentru a găsi o soluție viabilă în apărarea colectivă. 


\section{References}

70 Ways the UN Makes A Difference (n.d.). Retrieved from https://www.un.org/un70/en/content/70ways/index.html

BBC Romanian (2004, October 7th). 'Saddam Hussein nu avea arme de distrugere in masă'. Retrieved from

http://www.bbc.co.uk/romanian/news/story/2004/10/041007 raport d uelfer.shtml

Brown, G. (2008). This is how we will stand up to Russia's naked aggression. Retrieved from

https://www.theguardian.com/commentisfree/2008/aug/31/russia.georgi $\underline{\mathrm{a}}$

CNN Politics (2008). Study: Bush, aides made 935 false statements in run-up to war.

Retrieved from

http://edition.cnn.com/2008/POLITICS/01/23/bush.iraq/

Consiliul de Securitate O.N.U. Rezolutia nr. 1493/2003 adoptată de Consiliul de Securitate in cadrul celei de-a 4.797-a intruniri, la 28 iulie 2003. Retrieved from https://lege5.ro/Gratuit/geytinjirhe/rezolutia-nr-1493-2003-adoptata-deconsiliul-de-securitate-in-cadrul-celei-de-a-4797-a-intruniri-la-28-iulie-2003

Harding, L., \& Borger, J. (2008). Cheney attacks 'illegitimate' Russian invasion on visit to Georgia. Retrieved from https://www.theguardian.com/world/2008/sep/04/georgia.russia

Hotnews.ro (2008). VIDEO Cel mai cumplit carnagiu, in a unsprezecea zi de conflict. Cel putin 635 palestinieni au fost ucisi si aproape 3.000 au fost raniti in ofensiva israeliana din Fasia Gaza. Retrieved from https://www.hotnews.ro/stiri-international5304163-video-cel-mai-cumplit-carnagiu-unsprezecea-conflict-cel-putin635-palestinieni-fost-ucisi-aproape-3-000-fost-raniti-ofensiva-israeliana-dinfasia-gaza.htm

Human Rights Council (2009). HUMAN RIGHTS IN PALESTINE AND OTHER OCCUPIED ARAB TERRITORIES. Report of the United Nations Fact-Finding Mission on the Gaza Conflict. Retrieved from https://www2.ohchr.org/english/bodies/hrcouncil/docs/12session/AHRC-12-48.pdf

Maier, S. N. (2008). Consecintele razboiului din Georgia. Retrieved from https://acum.tv/articol/8895/

Nichol, J. (2009). Russia-Georgia Conflict in August 2008: Context and Implications for U.S. Interests. Retrieved from https://fas.org/sgp/crs/row/RL34618.pdf

Reuters (2008). Iraq conflict has killed a million Iraqis: survey. Retrieved from https://www.reuters.com/article/us-iraq-deaths-survey/iraq-conflict-haskilled-a-million-iraqis-survey-idUSL3048857920080130 
Reuters (2009). FACTBOX: Facts about the 2008 war in Georgia. Retrieved from https://www.reuters.com/article/us-georgia-war-conflict-sb/factboxfacts-about-the-2008-war-in-georgia-idUSTRE5732TH20090804

Statement by H. E. Dr. Haris Silyjdzic, Chairman of the Presidency of Bosnia and Herzegovina. (2008, September 23rd). Retrieved from http://www.responsibilitytoprotect.org/files/bosniaherzegovina en.pdf

UN News (2010). UN official warns Security Council that ethnic tensions remain high in Kyrgyzstan. Retrieved from https://news.un.org/en/story/2010/06/342942-un-official-warnssecurity-council-ethnic-tensions-remain-high-kyrgyzstan

United Nations, General Assembly (2000). Comprehensive review of the whole question of peacekeeping operations in all their aspects. Report of the Special Political and Decolonization Committee. Retrieved from https://www.un.org/documents/ga/docs/55/a55572.pdf

Wikipedia.org (n.d.). ORB survey of Iraq W ar casualties. Retrieved from: https://en.wikipedia.org/wiki/ORB survey of Iraq War casualties

Wikipedia.org (n.d.). United Nations Fact Finding Mission on the Gaza Conflict. Retrieved from

https://en.wikipedia.org/wiki/United_Nations_Fact_Finding_Mission_on the Gaza_Conflict

www.mae.ro 